\title{
GOLGA5/RET Fusion Gene
}

National Cancer Institute

\section{Source}

National Cancer Institute. GOLGA5/RET Fusion Gene. NCI Thesaurus. Code C99856.

A fusion gene ( $2.9 \mathrm{~kb})$ that results from a chromosomal translocation $\mathrm{t}(10 ; 14)(\mathrm{q} 11 ; \mathrm{q} 32)$

which fuses the 5' portion of the GOLGA5 gene and the 3' portion of the RET gene. This rearrangement is associated with papillary thyroid carcinoma. 